Uniwersytet im. Adama Mickiewicza, Poznań

\title{
Efektywność zmian w ukraińskim systemie wyborczym w procesie transformacji
}

Proces transformacji w Ukrainie został zapoczątkowany w 1991 roku byłych republik. A. Stelmach nazywa ten okres, ,przeobrażeniami ustrojowymi zachodzącymi w państwach realnego socjalizmu, które rozpoczęły procesy zmian politycznych mających w konsekwencji doprowadzić je do systemów demokratycznych"1.

Jedną z podstaw ustroju demokratycznego są wolne i uczciwe wybory, w tym sposób formowania władzy i mechanizmy jej kontroli. Wybory umożliwiają realizację zasady suwerenności narodu.

Aktualny system wyborczy Ukrainy jest wynikiem procesu przemian ustrojowych, jakie dokonały się w na początku lat 90-tych XX wieku po uchwaleniu nowej Konsytytucji Ukrainy w 1996 roku. Odpowiednie ustawodawstwo wyborcze ilustruje stopniowe przechodzenie narodu ukraińskiego do zasad demokracji, ewolucję rozwoju podstawowych zasad prawa wyborczego.

Podstawy prawa wyborczego są zawarte w Konstytucji, ustawie o wyborach Prezydenta Ukrainy, ustawie o partiach politycznych, ustawie o wyborach deputowanych do Rady Najwyższej Ukrainy, ustawie o Komisji Wyborczej.

Doświadczenie wyborcze społeczeństwa ukraińskiego obejmuje wybory deputowanych USRR w 1989 roku, wybory do Rady Najwyższej Ukrainy w latach 1990, 1994, 1998 i 2002, 2006, 2007, wybory prezydenckie w latach 1991, 1994, 1999, 2004 i 2010. Specyfiką Ukrainy są częste zmiany ustawodawstwa wyborczego - prawie przed każdymi wyborami - prezydenckimi czy parlamentarnymi. System polityczny jest systemem dynamicznym, co uzasadnia potrzeby zmian.

1 A. Stelmach, Zmiana i stabilność w systemie politycznym współczesnej Rosji, Poznań 2003, s. 17. 
Wojciech Sokół w systemie wyborczym na Ukrainie wyróżnia cztery główne etapy, przeplatane powtarzającymi się co cztery lata wyborami parlamentarnymi:

1) dyskusje nad nowym prawem wyborczym do ukraińskiego parlamentu w 1990 r., związane z uzyskaniem niepodległości;

2) lata 1991-1993: okres nieudanych prób wprowadzenia znaczących zmian do prawa wyborczego z ery radzieckiej przed pierwszymi postradzieckimi wyborami parlamentarnymi w 1994 r.;

3) lata 1994-1997: okres, w którym parlament debatował nad wieloma kwestiami związanymi z wyborami 1994 r. i przyjął mieszany system wyborczy w wersji paralelnej;

4) lata 1998-2005: okres, w którym rozważano dalsze kierunki reform, a następnie przyjęto zasadę reprezentacji proporcjonalnej.

Ustawodawstwo wyborcze ilustruje drogę narodu ukraińskiego do demokracji. Częste zmiany miały zarówno negatywny, jak i pozytywny wpływ na kształtowanie systemu wyborczego Ukrainy. Z jednej strony, utrudniało to praktykę stosowania ustawy podczas procesu wyborczego, z innej - tak częste zmiany były spowodowane szybkim rozwojem politycznym społeczeństwa ukraińskiego.

Przejście od jednego systemu wyborczego do innego nie było dla Ukrainy łatwe. Obecna sytuacja polityczna Ukrainy (w tym i w systemie wyborczym) na tle innych krajów wynika z uwarunkowań historycznych. Dla zrozumienia ewolucji systemu wyborczego oraz jego współczesnego stanu przeanalizujemy ważne czynniki, które miały wpływ na formowanie systemu władzy na Ukrainie: spuścizna sowiecka, społeczny podział kraju, powstanie oligarchów.

Ukraina była w składzie Związku Radzieckiego ponad 70 lat. Konstytucja USRR działała wyłącznie w ramach Konstytucji ZSRR i jej wpływ na życie społeczno-polityczne był niewielki, a w sferze praw i wolności obywatelskich był to dokument jedynie ,papierowy”. System wyborczy był jeden dla wszystkich republik: większościowy system wyborczy, fikcyjny charakter wyborów do rad i ich podporządkowanie partii komunistycznej, znany wcześniej wynik wyborów. W systemie radzieckim najwyższym organem władzy ustawodawczej była Rada Najwyższa Ukraińskiej SRR, w składzie 650 deputowanych, wybierana zwykłą większością głosów na

2 W. Sokół, Geneza i ewolucja systemów wyborczych w państwach Europy Środkowej $i$ Wschodniej, Lublin 2007, s. 483. 
pięcioletnią kadencję. Posiedzenia Rady Najwyższej odbywały się dwa razy w roku, deputowany miał jeszcze inne miejsce pracy. W przerwach pomiędzy posiedzeniami władza była w rękach Prezydium (25 osób), wybieranego ze składu deputowanych, na czele którego stał przewodniczący. Do kompetencji Prezydium należały funkcje właściwe zarówno władzy ustawodawczej, wykonawczej, jak i sądowniczej. Komunistyczna Partia była jedyną partią w ZSSR, w tym i w Ukrainie. Powszechne było propagowanie kultu wodzów partii, wiara w ich nieomylność i wszechwiedzę.

W ogóle taki system nie rozwijał społecznej świadomości politycznej, rodził wśród obywateli obawę, że myślą nie tak, jak wszyscy i wiarę, że państwo zadba o nich. Taka pozycja społeczeństwa ukraińskiego miała negatywny wpływ na wybory nawet w niezależnej Ukrainie.

I. Pankevych ${ }^{3}$ uważa, że w demokratycznym państwie istnieje społeczeństwo obywatelskie. Na Ukrainie ono dopiero kształtuje się. Przeszkodami jego rozwoju są rozwarstwienia majątkowe (większość obywateli znajduje się w trudnych warunkach materialnych), co przeszkadza rozwijaniu klasy średniej w społeczeństwie, oraz duża korupcja.

Nie mniej ważnym czynnikiem jest podział Ukrainy na część Wschodnią i Zachodnią. Znany publicysta M. Riabczuk w swojej książce Dwie Ukrainy porównuje zachód i wschód kraju na przykładzie dwóch miast - Lwowa i Doniecka. Lwów ,jest typowym miastem środkowoeuropejskim, uformowanym zgodnie z prawem magdeburskim i przez stulecia zachowującym autonomię municypalną”. Ukraińcy „zachodni” nigdy nie przyswoili do końca komunizmu, nie postrzegali Związku Radzieckiego jako do końca „własnego” kraju, Armię Czerwoną traktowano jako okupantów. Natomiast Donieck - to ,świat zwycięskiej rewolucji i proletariackiego internacjonalizmu; typowe sowieckie miasto, nie do odróżnienia od tysięcy innych industrialnych monstrów; są oni proletariaccy"5.

Różnica między wschodnią a zachodnią częściami Ukrainy jest nieduża, wiąże się ona z rozwojem gospodarczym (region bardziej uprzemysłowiony i rolniczy), tradycjami, położeniem geograficznym i sąsiedztwem (granica). Wyniki pierwszego w czasach postsowieckich spisu powszechnego przeprowadzonego na Ukrainie w 2001 r. pokazały, że kraj zamieszkuje prawie $78 \%$ Ukraińców i 17\% Rosjan. Także podczas spisu okazało się, że 85,2\% etnicznych Ukraińców uważa za język ojczysty ukraiński,

3 I. Pankevych, Zasady prawa wyborczego Ukrainy, Lublin 2008, s. 34.

4 M. Riabczuk, Dwie Ukrainy, Wrocław 2004, s. 29.

5 Ibidem, s. 30. 
zaś $14,5 \%$ - rosyjski. Nie ma w tym nic dziwnego - polityka rusyfikacji była prowadzona kilka stuleci, język ukraiński był postrzegany jako „wiejski”. Ciekawym faktem jest to, że 96\% Rosjan uznało za „swój” - język rosyjski. Najwięcej Ukraińców „ukraińskojęzycznych” mieszka na zachodzie kraju, a im dalej na południe i wschód - tym bardziej zwiększa się liczba Rosjan i rosyjskojęzycznych osób. Ale etniczność czy ojczysty język nie jest czymś bardzo ważnym dla wielu obywateli Ukrainy. Prawie w każdym kraju jest regionalny podział, co też zależy od wyżej wymienionych czynników. Wiadomo, że wyniki wyborów są różne na zachodzie i wschodzie Ukrainy, ale zależy to nie tylko od narodowości.

Byłego prezydenta Ukrainy L. Kuczmę oskarżają o to, że pod jego kierownictwem powstały klany oligarchiczne, które stały się podporą prezydenta. Ukraina zgodnie z Konstytucją jest krajem demokratycznym, dlatego klany oligarchiczne nie mogą funkcjonować bezpośrednio w polityce, więc musiały utworzyć partie polityczne. W. Baluk w swojej pracy Kształtowanie systemu partyjnego Ukrainy w okresie transformacji ustrojowej opisuje zjawisko ,partii władzy” - co było „reakcją elit postkomunistycznych na proces transformacji”, , „poziome” przejście komunistycznej elity politycznej w rządy nowej elity niezależnej Ukrainy. Profesor konstatuje, że „w warunkach wprowadzenia reguł demokratycznych, nomenklatura stanęła przed wyzwaniem zachowania kontroli nad społeczeństwem. Kierowniczą rolę KPZR należało przekształcić w mechanizm, przy pomocy którego nadal można byłoby sterować społeczeństwem. „Partia władzy” utożsamiała się z władzą, a nie z partią, dlatego też nie zależało jej na pomyślnym zakończeniu procesu demokratyzacji, a jedynie na zachowaniu władzy, w konsekwencji doprowadziło to do utkwienia Ukrainy w „szarej strefie demokracji",

Najpotężniejsze klany oligarchiczne powstały na wschodzie i południu Ukrainy, co jest spowodowane skupieniem ukraińskiego przemysłu ciężkiego i wydobywczego w tych regionach, także powiązanego dość mocno z państwami WNP, w tym z Rosja.

Wyżej wspomniano, że podczas kadencji eks-prezydenta Kuczmy na Ukrainie były stworzone partie władzy i oligarchiczne klany. Leonid Kuczma pracował w branży techniki rakietowej, a w latach 1982-1992 zajmował kierownicze stanowiska w jednym z największych w świecie

6 W. Baluk, Ksztaltowanie systemu partyjnego Ukrainy $w$ okresie transformacji ustrojowej 1987-2002, Wrocław 2006, s. 36.

7 Ibidem, s. 38. 
zakładów rakietowych „Piwdenne” w Dniepropietrowsku. Od 1990 roku był aktywnym politykiem, na propozycję największych ośrodków przemysłowych zgłosił swoją kandydaturę na prezydenta w przedterminowych wyborach 1994 roku.

Po zwycięstwie Kuczmy nad pozbawionym własnej bazy politycznej Krawczukiem, system oligarchiczny mógł rozwinąć się w pełni w oparciu o nomenklaturę przemysłową Wschodniej i Południowej Ukrainy. Partie były zakładane przez deputownych ludowych lub premierów w oparciu o biznesmenów z podległych im sektorów gospodarki, którzy w trosce o własne bezpieczeństwo i możliwość drenowania budżetu państwa nie mogli pozostać poza danym ugrupowaniem. Natomiast często masę członkowską takich partii stanowili pracownicy zakładów, co rzecz jasna nie ma nic wspólnego z rzeczywistym poparciem społecznym i tłumaczy masowość oligarchicznych organizacji politycznych w sytuacji zagrożenia bezrobociem. Partie proprezydenckie stanowią zaplecze polityczne prezydenta. Charakterystyczną cechą tego czasu była konserwacja (restauracja) postkomunistycznych socjalno-ekonomicznych realiów i faktyczne unikanie reform gospodarczych i politycznych.

W porównaniu z innymi byłymi republikami Związku Radzieckiego na Ukrainie na początku lat 90-tych istniała opozycja, która nawet przy kadencjach Kuczmy miała poważny wpływ na politycznej arenie kraju. Także ważnym czynnikiem jest to, że walka polityczna na Ukrainie przebiegała i przebiega pokojowo. W celu osłabienia konkurentów politycznych każda $\mathrm{z}$ sił odwołuje się do argumentów prawnych i arbitrażu sądowego, zamiast do rozwiązań siłowych czy wojskowych. Warto zauważyć, że konkurencja między proprezydenckimi partiami i opozycją - to walka między oligarchicznymi klanami i biznesowymi grupami o strefy wpływu.

Wymienione wyżej czynniki wpłynęły na system wyborczy Ukrainy, niestety bardziej negatywnie, niż pozytywnie. Jednakże na przestrzeni WNP Ukraina pozostaje krajem najbardziej demokratycznym i otwartym.

Od czasów pierestrojki zaczęły się zmiany ustawodawstwa wyborczego w Związku Radzieckim, w tym i w URRS. Wybory w latach 1989-1990 można uznać za pierwsze wybory w pewnym stopniu demokratyczne w całym Związku Radzieckim. Partia komunistyczna była jedyną partią. 27 października 1989 r. Rada Najwyższa uchwaliła „Ustawę o wyborach deputowanych ludowych USRR". Po raz pierwszy wprowadzono możliwość zgłoszenia niezależnych kandydatów na deputowanych ludowych, na jeden mandat deputowanego $\mathrm{w}$ terytorialnych okręgach wyborczych 
kandydowało kilka osób. Wybory odbywały się w w 450 jednomandatowych okręgach wyborczych.

Wybory w okręgu wygrywał ten kandydat na deputowanego, który otrzymał w wyborach więcej niż połowę głosów wyborców, którzy wzięli udział w głosowaniu, przy frekwencji wynoszącej co najmniej 50\%. W przypadku niespełnienia tych kryteriów przez żadnego z kandydatów zarządzano powtórkę wyborów. Ale w powtórnych wyborach mogli uczestniczyć tylko dwaj kandydaci, którzy uzyskali najlepsze wyniki. Prawo do zgłaszania kandydatów otrzymywały kolektywy pracownicze, organizacje społeczne oraz zebrania wyborców według miejsca zamieszkania $^{8}$.

Jak słusznie zauważa profesor Pankevych „chociaż starcia w ukraińskim parlamencie I kadencji były bardzo burzliwe, jednak właśnie ten czas można scharakteryzować jako etap przekształcenia ukraińskiej «radzieckiej» Rady Najwyższej w organ pełniący realne funkcje władzy ustawodawczej niezawisłego kraju, w którym zasada władzy ludu nie jest tylko deklaracjac, ale ma realną treść. Podobnie jak w innych republikach byłego ZSRRR, Radę Najwyższą Ukraińskiej RSR tylko teoretycznie można było określać mianem parlamentu dlatego, że nie obowiązywała zasada podziału władz i brakowało stale obradującego wyższego organu przedstawicielskiego"9.

Pierwsze wybory prezydenckie odbyły się też w 1991 r. Największe poparcie otrzymał Przewodniczący Rady Najwyższej URRS - L. Krawczuk (61,59\% poparcia wyborców). Były dysydent Taras Czornowił przegrał $(23,27 \%$ poparcia wyborców), co świadczyło, że opozycja w republice radzieckiej była jeszcze dość słaba i społeczeństwo było jeszcze niegotowe na kardynalne zmiany polityczne. Ciekawym faktem jest to, że Czornowił otrzymał największe poparcie wyborców w kilku obwodach Zachodniej Ukrainy - lwowskim, iwano-frankowskim, tarnopolskim, rówieńskim i wołyńskim.

Początek lat 90. - to czas kryzysu w gospodarce (hiperinflacja, spadek PKB i produkcji), złożonej sytuacji społecznej i poważnych zmian w polityce kraju. Kadencja pierwszego parlamentu i pierwszego prezydenta niezależnej Ukrainy trwały zaledwie niecałe 3 lata. W połowie 1993 r. doszło

8 O. Klużew, Prawowi determinanty parlamentskich kampanij na Ukraini: wyborcze prawo ta politycznyj aspekt, http://www.nbuv.gov.ua/portal/natural/Nvuu/ PSF/2009_12/Kluzhev.pdf, 29.05.2010.

9 I. Pankevych, Zasady..., op. cit., s. 164. 
do kryzysu parlamentarno-prezydenckiego. Podjęto wtedy decyzję o przeprowadzeniu przedterminowych wyborów do Rady Najwyższej Ukrainy i na Prezydenta Ukrainy w marcu 1994 r. Wybory przeprowadzono na zasadzie nowej ustawy o wyborach deputowanych ludowych z 7 października 1993 r. W ustawie wprowadzono następujące zmiany:

- skrócono kadencję Rady Najwyższej Ukrainy z pięciu lat do czterech;

- podniesiono dolny próg wieku wyborczego z 21 do 25 lat, wraz z zasadą, że kandydat przez ostatnie dwa lata powinien mieszkać w kraju;

- prawo do zgłaszania kandydatów uzyskali obywatele, partie polityczne i kolektywy pracownicze;

- wprowadzono zasadę ciagłej pracy parlamentu;

- przewidziano wymóg depozytu finansowego (pięć minimalnych pensji), który miał ograniczyć nadmierną liczbę kandydatów;

- zezwolono na posiadanie prywatnego funduszu wyborczego, który nie mógł przekroczyć 100 minimalnych pensji.

W ustawie najpierw wprowadzono przepis o apelacji do Sądu Najwyższego Ukrainy, jeżeli przedstawiciele partii politycznej czy deputowany ludowy postępują niezgodnie z decyzją Centralnej Komisji Wyborczej. Sąd wydawał ostateczną decyzję. W ustawodawstwie wyborczym Radzieckiej Ukrainy takiego prawa nie było.

Po raz pierwszy w wyborach uczestniczyła więcej niż jedna partia. Oficjalnie podczas kampanii wyborczej do parlamentu byli zarejestrowani kandydaci aż 28 partii politycznych. Chociaż najpotężniejszymi partiami w tych wyborach były - Partia Komunistyczna Ukrainy i Narodowy Ruch Ukrainy. W tym do parlamentu trafiło 91 kandydatów Partii Komunistycznej, 22 - Narodowego Ruchu, 21 - Chłopskiej Partii Ukrainy, 14 - Socjalistycznej Partii Ukrainy. Z 405 deputatów ludowych tylko 178 było przedstawicielami jakiejś partii politycznej, pozostali byli bezpartyjni $^{10}$.

Niestety w wyborach do parlamentu II kadencji pozostał odziedziczony po Związku Radzieckim system większościowy. Miało to negatywne skutki. Frekwencja wyborców była zbyt niska w porównaniu z czasami radzieckimi. Na deputowanych do parlamentu w marcu 1994 r. zgłosiło się 5609 kandydatów, ale wybranych zostało tylko 49; w kwietniu po powtórnych wyborach doszło jeszcze 289 osób. Na początku pracy parlamentu było tylko 336 deputowanych zamiast 450 . Wyborcy 30 okręgów

10 O. Klużew, Prawowi determinanty..., op. cit. 
wyborczych nie mieli swoich przedstawicieli w parlamencie do końca jego kadencji ${ }^{11}$.

Warto jeszcze zaznaczyć, że obecna Partia Komunistyczna Ukrainy „została zarejestrowana 22 lipca 1991 roku jako zrzeszenie obywateli, nie była spadkobiercą Komunistycznej Partii Związku Radzieckiego i Komunistycznej Partii Ukrainy mającej miejsce w składzie KPZR"12.

Rada Najwyższa II kadencji przeszła do historii ukraińskiego parlamentu, ponieważ podczas jej sprawowania została przyjęta Konstytucja niezależnej Ukrainy (w 1996 roku); co prawda najpóźniej ze wszystkich byłych republik Związku Radzieckiego.

Równocześnie z wyborami do Parlamentu odbyły się wybory Prezydenta Ukrainy. O fotel prezydencki rywalizowało 11 kandydatów. Od początku było zrozumiałe, że prawdziwa walka rozgrywa się między dwoma kandydatami - L. Krawczukiem i L. Kuczmą. Zwyciężył Kuczma z 52,5\% poparcia wyborców. Często jego kadencja w latach 1994-2004 nazywana jest reżimem. W 1995 r. przyjęto Umowę Konstytucyjną o podstawowych zasadach organizacji władzy państwowej i samorządu lokalnego na Ukrainie, która przyznała Prezydentowi Ukrainy maksimum władzy, zwalniając go de facto z politycznej i prawnej odpowiedzialności.

Przed kolejnymi wyborami do Parlamentu w 1998 r. wprowadzono nową „Ustawę o wyborach deputowanych ludowych Ukrainy”. Nowa ordynacja istotnie zmieniła prawo wyborcze, wprowadzając system większościowo-proporcjonalny. Połowa składu parlamentu miała zostać wyłoniona w ogólnopaństwowym okręgu wyborczym, według list krajowych partii politycznych i bloków wyborczych na zasadach proporcjonalnych. 225 deputowanych ludowych wybierano według systemu proporcjonalnego w wielomandatowym ogólnopaństwowym okręgu wyborczym według list wyborczych kandydatów na deputowanych utworzonych przez partie polityczne oraz bloki wyborcze partii politycznych, które przekroczyły 4-procentowy próg zaporowy. Drugą połowę - pozostałych 225 deputowanych - wybierano według systemu większości względnej w jednomandatowych okręgach wyborczych. Profesor Pankevych podkreśla, że taki system był „optymalny” w okresie przejściowym, bowiem z jednej strony pozwalał wyborcy zorientować się co do osoby konkretnego kandydata,

11 Historia ukraińskich wyborów, http://www.parlament.org.ua/index.php?action=publication\&id=8\&ar_id=11\&iar_id=316\&as=2, 29.05.2010.

${ }^{12}$ I. Pankevych, Zasady..., op. cit., s. 165. 
zaś z drugiej strony - wesprzeć daną siłę polityczną, z którą wyborca sympatyzowat"13.

Podczas wyborów do parlamentu w 1998 roku mogli głosować więźniowie. $Z$ jednej strony, nadawało to takim osobom większe prawa i było aprobowane przez obrońców praw człowieka, z drugiej strony - część naukowców uważa, że to była jedna z możliwości fałszowania wyborów.

Polityczna elita kraju zdecydowała, że więcej nie będzie ryzykować. Dlatego w ustawodawstwie wyborczym 1998 r. zniesiono minimalną frekwencję wyborców.

Pomimo uchwalenia w 2001 roku nowej „Ustawy o wyborach deputowanych ludowych Ukrainy", system wyborczy praktycznie pozostał bez zmian.

Najwięcej dyskusji wśród naukowców i politologów toczyło się wokół zmiany systemu wyborczego w latach 1998-2002.

Ukraiński politolog O. Klużew ${ }^{14}$ uważa, że Prezydent Kuczma nie zamierzał rezygnować ze swojej władzy, dlatego popierał koncepcje wprowadzenia systemu proporcjonalnego. W wyborach 1998 roku sukces odniosły proprezydenckie partie i bloki (w tym Narodowo-Demokratyczna Partia, Chłopska Partia Ukrainy etc.). Pod koniec lat 90. w Ukrainie zaczęły rozwijać się antyprezydenckie siły polityczne (Blok Wiktora Juszczenki, Blok Julii Tymoszenko). Dlatego większościowy system wyborczy pozostawiał możliwość wpływu Prezydenta na Parlament. Profesor Pankevych ${ }^{15}$ jest przekonany, że ,,bez wątpienia można powiedzieć (z czym zgadza się większość ukraińskich politologów, zajmujących się problematyką wyborczą), że dzięki ustawie wyborczej z dnia 18 października 2001 roku reżim polityczny Prezydenta Kuczmy mógł przetrwać do końca 2004 roku. W marcu 2002 roku opozycja na czele z Wiktorem Juszczenką odniosła sukces, wygrywając wybory parlamentarne $\mathrm{w}$ wielomandatowym ogólnopaństwowym okręgu wyborczym, ale nie zdołała sformować większości parlamentarnej w Radzie Najwyższej Ukrainy, gdyż w jednomandatowych większościowych okręgach wyborczych wybory wygrali kandydaci, popierani przez Prezydenta Kuczmę".

13 I. Pankevych, Zasady..., op. cit., s. 168.

14 O. Klużew, Prawowi determinanty..., op. cit., s. 7.

15 I. Pankevych, Zasady..., op. cit., s. 169. 
Pomarańczowa rewolucja wniosła poważne zmiany w systemie wyborczym Ukrainy, umożliwiła zaistnienie rzeczywistej konkurencji i walki politycznej na Ukrainie.

Przed wyborami parlamentarnymi w 2004 roku nastąpiła kolejna zmiana prawa wyborczego. W marcu 2004 roku weszła w życie nowa ustawa o wyborach deputowanych Ukrainy, do której po roku wniesiono kolejne zmiany. To głównie dotyczyło:

- utworzenia ogólnych list wyborców i regulamin ich uzupełniania, utworzenie specjalnych grup roboczych dla obliczenia wyborców w organach władzy samorządu lokalnego, gdzie w razie potrzeby sygnalizowano, że wyborca nie może $\mathrm{z}$ powodu stanu zdrowia samodzielnie przybyć do lokalu wyborczego;

- podwyższenia stopnia ochrony przed możliwymi nadużyciami podczas wydawania zaświadczeń, upoważniających do głosowania w innym okręgu wyborczym: druki takich zaświadczeń są ściśle obliczane, informację o wydaniu takiego zaświadczenia wpisuje się do paszportu wewnętrznego, ograniczono ilość lokali, gdzie można głosować posługując się tymi zaświadczeniami (jeden lokal przypada na miasto lub rejon wiejski);

- przyznania prawa do obserwacji wyborów przedstawicielom organizacji społecznych, których działalność statutowa przewiduje udział w procesach wyborczych;

- umożliwienia dostępu do protokołów z obliczenia głosów i wynikach głosowania;

- udoskonalenia przepisów, regulujących tryb zaskarżenia naruszeń prawa podczas przygotowania i przeprowadzenia wyborów.

Profesor Baluk podkreśla, że główną cechą nowych zmian stało się „uczynienie z partii politycznych najważniejszych podmiotów elekcji parlamentarnej. Partie otrzymały prawo do zgłaszania kandydatów, umieszczając ich na liście krajowej"16. To stało się instrumentem porozumienia potężnych sił politycznych, osiagnniętego w procesie rozwiązywania konfliktu w ostatnich wyborach prezydenckich w 2004 roku. Wiadomo, że walka na ukraińskiej scenie politycznej toczy się nie tylko o realizację interesów politycznych, ale przede wszystkim biznesowych. Na Ukrainie bezpieczeństwo inwestycji zależy bowiem od gwarancji politycznych. Najbogatsi ukraińscy oligarchowie są więc silnie związani z liderami i par-

16 M. Baluk, Ksztattowanie systemu partyjnego Ukrainy..., op. cit., s. 259. 
tiami politycznymi. W zamian za finansowanie ich kampanii wyborczych i popieranie inicjatyw politycznych przedstawiciele wielkiego biznesu uzyskują dostęp do władzy - obejmują wysokie stanowiska państwowe, kształtują politykę, a także otrzymują przychylność władz wobec prowadzonych przez nich interesów.

Kompromis, który wzmocni wpływ partii politycznych w procesie wyborczym, był założony jeszcze w zmianach do Konstytucji w 2004 roku. Między innymi, prowadzenie wyborów z wykorzystaniem metody proporcjonalnej (według list partyjnych), obniżenie progu wyborczego do 3\%.

W 2007 roku Prezydent Ukrainy Wiktor Juszczenko rozwiązał Radę Najwyższą V kadencji i wyznaczył przedterminowe wybory parlamentarne. Ta decyzja sprowokowała konflikt wewnętrzny w kraju. Kolejne zmiany w ustawodawstwie wyborczym i nowy parlament dużo nie zmieniły na arenie politycznej Ukrainy. Sytuacja uległa zmianie po wyborach nowego Prezydenta Ukrainy - Wiktora Janukowycza w 2010 roku. Nowa władza decyduje o nowych zmianach w systemie wyborczym. Kolejne wybory do Parlamentu będą już za rok - w marcu 2011 roku.

Wybory do Rady Najwyższej w 1990 roku pozostawiły cechy wyborów radzieckich, ale miały duże znaczenie dla kształtowania się nowego systemu wyborczego Ukrainy. Od czasu zdobycia niepodległości w 1991 r. ustawy wyborcze wielokrotnie nowelizowano, w Ukrainie funkcjonowało kilka systemów wyborczych. Proces budowania demokratycznego społeczeństwa na Ukrainie był skomplikowany.

\section{Bibliografia}

Klużew O., Prawowi determinanty parlamentskich kampanij na Ukraini: wyborcze prawo ta politycznyj aspekt, http://www.nbuv.gov.ua/portal/natural/Nvuu/ PSF/200912/Kluzhev.pdf.

Historia ukraińskich wyborów, http://www.parlament.org.ua/index.php?action=publication\&id=8\&ar_id=11\&iar_id=316\&as $=2$.

Pankevych I., Zasady prawa wyborczego Ukrainy, Monografie naukowe WSEI, Lublin 2008.

Riabczuk M., Dwie Ukrainy, Kolegium Europy Wschodniej, Wrocław 2004.

Sokół W., Geneza i ewolucja systemów wyborczych w państwach Europy Środkowej $i$ Wschodniej, Wydawnictwo UMCS, Lublin 2007.

Stelmach A., Zmiana i stabilność w systemie politycznym wspótczesnej Rosji, Wydawnictwo Naukowe UAM, Poznań 2003. 


\section{Summary}

Over the period of its independence, Ukraine has gone through several stages of modernization of its electoral system, moving from system of absolute and mixed majority to proportional representation. What can this signify? Either the democratic principles of the national political system are strengthening and political institutions fully function in society, or a system of state authorities has actually transformed into the rule of oligarchic parties which control the activities of the government via parliament and are sufficiently independent from the President. By virtue of the constitutional reform from late 2004, Ukraine has transformed into a parliamentary-presidential republic, where the parliament is the core of control over executive power. Therefore, it is quite significant which parties win the elections. 